\title{
Screening for child abuse at emergency departments: a systematic review
}

Eveline C F M Louwers, Maria J Affourtit, Henriette A Moll, Harry J de Koning and Ida J Korfage

Arch. Dis. Child. published online 21 Sep 2009;

doi:10.1136/adc.2008.151654

Updated information and services can be found at:

http://adc.bmj.com/cgi/content/abstract/adc.2008.151654v1

These include:

Open Access This article is free to access

Rapid responses You can respond to this article at:

http://adc.bmj.com/cgi/eletter-submit/adc.2008.151654v1

Email alerting Receive free email alerts when new articles cite this article - sign up in the box at the service top right corner of the article

\section{Notes}

Online First contains unedited articles in manuscript form that have been peer reviewed and accepted for publication but have not yet appeared in the paper journal (edited, typeset versions may be posted when available prior to final publication). Online First articles are citable and establish publication priority; they are indexed by PubMed from initial publication. Citations to Online First articles must include the digital object identifier (DOIs) and date of initial publication.

To order reprints of this article go to:

http://journals.bmj.com/cgi/reprintform

To subscribe to Archives of Disease in Childhood go to:

http://journals.bmj.com/subscriptions/ 


\section{TITLE:}

Screening for child abuse at emergency departments: a systematic review

\section{AUTHORS:}

Eveline C.F.M. Louwers, MD ${ }^{1,2,3}$, PhD student

Marjo J. Affourtit, $\mathrm{MD}^{2}$, paediatrician

Henriëtte A. Moll, MD PhD', professor of paediatrics

Harry J. de Koning, MD PhD', professor of Public Health

Ida J. Korfage, $\mathrm{PhD}^{1}$, post-doc researcher

\section{AFFILIATIONS:}

${ }^{1}$ Dept. of Public Health, P.O. Box 2040, 3000 CA Rotterdam, Erasmus MC, University Medical Center Rotterdam, the Netherlands

${ }^{2}$ Dept. of Paediatrics, P.O. Box 2060, 3000 CB Rotterdam, Erasmus MC-Sophia Children's Hospital, the Netherlands

${ }^{3}$ Netherlands Institute for Health Sciences, Erasmus MC, University Medical Center

Rotterdam, the Netherlands

\section{CONTACT DETAILS:}

Address:

E.C.F.M. Louwers

Erasmus MC

Dept. of Public Health

Room Ae-107

P.O. Box 2040

3000 CA Rotterdam

The Netherlands

Tel. no. : $\quad+31107043422$

Fax no:: $\quad+31107038475$

E-mail: $\quad$ e.louwers@erasmusmc.nl

\section{KEYWORDS:}

"child abuse"(MESH), "mass screening" (MESH), "emergency service, hospital" (MESH), "review literature as topic" (MESH).

\section{WORD COUNT:}

2406 words 
Screening for child abuse at emergency departments: a systematic review

\section{ABSTRACT \\ Introduction}

Child abuse is a serious problem worldwide and can be difficult to detect. Although children who experience the consequences of abuse will probably be treated at an emergency department, detection rates of child abuse at emergency departments remain low. Objective

To identify effective interventions applied at emergency departments that significantly increase the detection rate of confirmed cases of child abuse.

Design

This review was carried out according to the Cochrane Handbook. Two reviewers individually searched Pubmed, The Cochrane Library, EMBASE, Web of Science, and CINAHL for papers that met the inclusion criteria.

Results

Fifteen papers describing interventions were selected and reviewed; four of these were finally included and assessed for quality. In these studies the intervention consisted of a checklist of indicators of risk for child abuse. After implementation, the rate of detected cases of suspected child abuse increased by $180 \%$ (weighted mean in 3 studies). The number of confirmed cases of child abuse, reported in two out of four studies, showed no significant increase.

\section{Conclusions}

Interventions at emergency departments to increase the detection rate of cases of confirmed child abuse are scarce in the literature. Past study numbers and methodology have been inadequate to show conclusive evidence on effectiveness. 


\section{INTRODUCTION}

Child abuse is one of the most serious and devastating problems in childhood. The number of children that are abused has long been underestimated. According to estimations from the World Health Organization (WHO) in 2002 almost 31,000 children aged under 15 years died worldwide as a result of homicide.[1] The incidence of child abuse in the USA is estimated at 23.1 per 1,000 children [2, 3] and in the Netherlands at 30 per 1,000 children.[3] In this report child abuse refers to 'all forms of physical and emotional ill-treatment, sexual abuse, neglect, and exploitation that result in actual or potential harm to the child's health, development or dignity', as defined by the WHO.[4]

Early detection and intervention may help to halt child abuse and limit the damage to the development of the child.[5] Although child abuse can be difficult to detect, it is likely that children who experience the consequences of abuse will be treated at emergency departments (ED). The incidence rates of child abuse at ED have been reported to range from $2 \%$ [6-8] to as high as 10\%.[9-13] However, the detection rate of child abuse at ED in the Netherlands (assessed for 2001-2004) was only 0.1\%.[14] If the medical staff, e.g. at ED, would systematically be aware of the possibility of child abuse in each child they see, the detection rate might increase.

Introduction of a uniformly applicable protocol for screening for child abuse could be beneficial if such a screening is effective and if a simultaneous increase of incorrect suspicions of child abuse can be prevented. The aim of this review is to establish whether an effective intervention exists that is to be used at ED and that significantly increased the detection rate of confirmed cases of child abuse.

\section{METHODS}

The information for this review was obtained according to the Cochrane Handbook.[15] In February 2008 a search was made of PubMed, EMBASE, Web of Science, The Cochrane Library and CINAHL. No limitations were applied for languages or date of publication. To ensure that all critical papers were included, the journal 'Child Abuse and Neglect' was reviewed from 1977. The search was started in PubMed and used the Medical Subject Heading Terms "child abuse", "mass screening", and "emergency service, hospital" and eight other related keywords (battering, non-accidental injury, maltreatment, screening, intervention, emergencies, emergency treatment, emergency department), separately and in combination.

The following inclusion criteria were applied: 1) studies should be peer reviewed and focus on children; 2) the context should be an emergency department; and 3) an intervention to detect child abuse must have been used. Furthermore, studies aimed at specific patient groups (such as children with burns) were excluded, since results of these studies would not be generalizable to the ED setting. When titles and abstracts met the inclusion criteria, these were screened independently by two reviewers (EL, IK). The selected studies were rated on study design, the included age range, whether all presenting symptoms were included or only cases of trauma, and whether suspected cases of child abuse could be confirmed in the follow-up. Each paper was assessed for these four criteria; when a criterion was adequately met, one point was allocated. The reviewers jointly reached a consensus on inclusion or exclusion criteria of the papers and on the allocation of points.

An intervention was considered effective if due to the intervention the rate of cases of confirmed child abuse increased significantly.

\section{RESULTS}

The search in PubMed resulted in 328 titles; no new studies were found in the other databases. From these titles, 318 studies were excluded based on the title and/or the lack of an abstract. Based on titles and abstracts, 10 papers appeared to fulfill the inclusion criteria.[8, 9, 13, 16-22] An additional 3 papers were added from the reference lists [23-25], and 2 Dutch papers known to the reviewers were also included.[14, 26] Of the resulting 15 papers, the full articles were read by the two reviewers. Subsequently, 11 articles were excluded because they did not specifically meet the inclusion criteria, i.e. 1 was not a peer- 
reviewed study [26], and in 10 studies the intervention was not applied in practice.[8, 16-20, 22-25]

Therefore, 4 studies were finally included in this review which together reported on 8,987 children aged $0-18$ years (Table 1 ).[9, 13, 14, 21]

Pless et al. introduced The Montreal Children's Hospital Accident Scan for 4,422 trauma patients aged up to 6 years presenting at ED (Table 2$)$. This prospective study showed a nonsignificant increase of confirmed cases of abuse from initially $0.86 \%$ up to $1.13 \%$ after implementing the intervention. The authors reported $25(70 \%)$ 'true positives' out of 36 children suspected of abuse after the intervention. Pless et al. concluded that either implementation of the checklist was not sufficient to increase the detection rate of child abuse, or that the ED staff was already focused on detecting child abuse.[13]

In the study of Sidebotham et al., all 2,345 children aged up to 18 years who attended the ED were included. Triage by nurses of the children attending the ED included checking the child protection register and assessing five indicators of risk for child abuse (Table 2). Two audits of two months each were done. After the first audit, training and feedback were given to the ED staff and the checklist was revised. During the second audit, a significant increase in suspected cases of abuse was seen ( $0.22 \%$ vs $1.32 \%$, OR 6.0 ), but whether these suspicions were confirmed in a later stage was not examined. The authors concluded that using a checklist will increase the awareness of child abuse in ED staff, but that child abuse cannot be identified solely through assessing five indicators of risk for child abuse.[21]

Benger et al. performed a prospective study with 2,000 trauma patients aged up to 6 years presenting at the ED. There were two audits of three months each; after the first audit a flowchart was introduced for the patient files consisting of four questions (Table 2). This flowchart was included in $71.7 \%$ of the patient files. After the introduction of the intervention, a much greater proportion of ED notes recorded consideration of intentional injury (71\%) than in the first audit (1.6\%), even in the notes without a flowchart. The increase in cases of suspected abuse was nonsignificant $(0.6 \%$ vs $1.4 \%$, OR 2.3$)$. Due to local policies the authors were not allowed to assess whether these suspected cases of child abuse were confirmed in a later stage.[9]

In a Dutch study of Bleeker et al., a checklist (named SPUTOVAMO) was introduced (Table 2). Numbers of detected cases before the intervention were not registered. After introduction of the intervention, child abuse was detected in $0.1 \%$ of all children presenting at the ED. Out of 220 suspected cases of abuse in the hospital (not only the ED), 58 (26\%) cases of child abuse could be confirmed.[14]

In the 3 studies for which numbers of children were reported, the detection rate of suspected or confirmed cases of child abuse increased by $179.9 \%$ (weighted mean). Figure 1. shows the trends per study. [9, 13, 21] Although the study of Pless et al. was the only one that provided follow-up confirmation of the suspected cases of abuse, the studies of Sidebotham et al. and Bleeker et al. satisfied most of the criteria in the quality assessment (Table 3 ).

\section{DISCUSSION}

In this review we found only 4 studies reporting an intervention to increase the detection rate of child abuse at emergency departments. In none of these studies could a significant increase in the detection of confirmed abuse in children be established after the introduction of an intervention at the ED. However, all studies reported an increase in the rate of suspected cases of abuse after the introduction of an intervention, as well as improved documentation of patient files, and a higher level of awareness of child abuse among ED staff, which are worthwhile effects of these interventions.[9, 13, 14, 21]

One risk associated with the introduction of screening for child abuse is an increase in the rate of incorrect suspicions without an increase of confirmed cases, which can be harmful for families. In 2 of the 4 studies in this review, the authors reported the number of cases of confirmed abuse. In the study of Pless et al., 11 of the 36 cases (30\%) were found to be true accidents after a full assessment [13], indicating child abuse had not occurred. Bleeker et al. reported 58 (26\%) confirmed cases out of 220 suspected cases; 120 suspected cases were refuted and in 42 cases no evidence was obtained.[14] The wide range between these studies may be related to the protocol used, or the population attending the ED; this stresses the importance of not accusing a possible perpetrator but rather to focus on the child's well being and conducting larger studies. 
Screening for child abuse at ED can also have positive side effects. When structured registration forms were used, documentation of the consideration of child abuse and documentation of risk factors increased.[9, 21, 23, 24, 27-29] Improved documentation is beneficial not only for other medical staff involved, but also in the event of a judicial investigation. Another positive effect of using checklists was that it heightened awareness; for example, in the case that the checklist was mistakenly not added to the medical records, the ED staff would still consider the possibility of child abuse and be better able to report this.[9, $21,27,30]$

The studies by Flanagan et al. and Limbos et al. showed that the standard indicators of child abuse were not always sought by physicians, suggesting the need for an aide-memoir $[17,24]$, such as a checklist of indicators of risk for child abuse. In 1979, Hight et al. developed a risk profile for children with burns to improve the recognition of child abuse.[31] After the introduction of Hight's profile, Clark et al. reported an increase of suspected cases of child abuse in burned patients and a significant increase in effective referrals to social services.[29] Benger et al. also introduced a reminder checklist for burned patients after which they saw a significant increase in the documentation of the risk indicators of child abuse and an (nonsignificant) increase in the referral rate.[27] In addition, according to Clark et al. there are many barriers for physicians to report child abuse, including lack of information, fear of litigation, and fear of creating an adversarial role between the doctor and the family. The use of a checklist and a clear protocol can help to break down some psychological barriers against reporting abuse.[29]

However, recording risk factors alone may be insufficient: the education of ED staff is essential to support screening.[14, 17-21, 27, 28] Van Haeringen et al. emphasized the importance of educating physicians: child abuse should not be missed because of lack of knowledge, or because physicians are ignorant of child abuse.[32]

Table 2 shows the items included in the checklists of the studies in this review. One or more disconcerting items are considered as a reason to suspect child abuse and to consult the pediatrician. Three items were included in all checklists: 1) whether the findings on examination conformed with the history given by the child or parents, 2) whether there was a delay in seeking medical help, and 3) whether there was an inconsistent history. Clark studied the effect of a screening profile in children with burns; he found that items 1 and 3 were significantly associated with referral for child protective services. Item 2 was found not to be significantly related. [29] However, we recommend further study on the predictive value of each of the items separately in studies with larger case numbers.

Some studies reported that younger children are at greater risk of abuse than older ones [10,11,29], but as reported by others also school-age children are often victim of abuse. [14, 17, 24, 31, 33] Two studies in this review implemented screening only in preschool children [9, 13], the other two did not make a selection for age.[14, 21] The odds ratio of the detection of child abuse through a checklist was much higher in the study of Sidebotham et al. that screened all age groups, compared to the studies that screened children up to 6 years of age (Table 1).

The incidence of child abuse at ED has been estimated as 2\% [6-8] up to as high as $10 \%$.[9-13] The incidence of $10 \%$ was based on estimations in older studies while the incidence of $2 \%$ was based on more recent assessments. However, even the more recent assessments remain an educated guess since child abuse cannot be measured in the same way as, for instance, obesity. There is a taboo associated with child abuse and often it cannot be seen from the outside. In this review, the incidence of suspected cases of child abuse after introduction of an intervention ranged from $0.1 \%$ to $2.3 \%$. Although this number is low, it still represents a large number of children and child abuse remains an important public health problem.

The number of studies in this review is very small. Although we retrieved a large number of publications using a sensitive search strategy according to the Cochrane Handbook [15], searched in five different databases, and did not exclude studies based on language, many studies did not fulfil the inclusion criteria. Two of the assessed papers were not identified through our search strategy; one was not present in the databases we searched [26], and the other did not correspond with the Mesh terms.[14] Nevertheless, because we were already aware of these two Dutch studies we were able to assess them. However, we acknowledge the possibility that other ('grey') publications describing screening for child abuse at ED may have been published but were not found by us on this occasion. The weighted mean has to be considered as an indication of the effects of the studies, since we 
pooled 3 studies in which 2 different quantities (suspected cases vs confirmed cases) were used.

We conclude that interventions at ED to increase the detection rate of cases of confirmed abuse could be effective, but currently there is no conclusive evidence to confirm this. Maybe the benefits are small and past study numbers and methodology have been inadequate to prove that benefit. To supply this evidence we recommend further research in large study populations including measuring of the detection rate of child abuse before and after the implementation of an intervention. 


\begin{tabular}{|c|c|c|c|c|c|c|c|c|c|}
\hline Article & Patients & $\begin{array}{l}\text { Duration of } \\
\text { study } \\
\text { follow- up }\end{array}$ & Country & Aim of study & $\begin{array}{l}\text { Type of } \\
\text { research }\end{array}$ & $\begin{array}{l}\text { Intervention implemented } \\
\text { during study }\end{array}$ & $\begin{array}{l}\text { Detection rate } \\
\text { before and after } \\
\text { intervention }\end{array}$ & Conclusion of study & $\begin{array}{l}\text { Effective screening } \\
\text { method according } \\
\text { to reviewers }{ }^{\star}\end{array}$ \\
\hline $\begin{array}{l}\text { Pless et al. Child } \\
\text { Abuse Negl 1987; } \\
\text { 11: 193-200 [13] }\end{array}$ & $\begin{array}{l}-0-5 \text { yrs } \\
- \text { Trauma } \\
\text { - } n=4422\end{array}$ & 4.5 months & Canada & $\begin{array}{l}\text { To test the hypothesis that a } \\
\text { more systematic evaluation of } \\
\text { all children with accidents } \\
\text { would increase the no. of } \\
\text { patients referred to the CPT } \\
\text { because of suspected } \\
\text { maltreatment and thereby } \\
\text { result in an increased no. of } \\
\text { subsequently confirmed cases }\end{array}$ & Prospective & $\begin{array}{l}\text { Introduction of the Accident- } \\
\text { SCAN, a checklist with } 10 \\
\text { questions for assessing the } \\
\text { risk of child abuse, filled in by } \\
\text { nurses who received special } \\
\text { training. In combination with } \\
\text { findings of the physician at } \\
\text { physical examination }\end{array}$ & $\begin{array}{c}\text { Increase of confirmed } \\
\text { cases of abuse and } \\
\text { neglect } \\
0.86 \% \rightarrow 1.13 \% \\
\text { OR } 1.32 \\
95 \% \mathrm{Cl} 0.72-2.40\end{array}$ & $\begin{array}{l}\text { No significant increase of } \\
\text { detection of abuse after } \\
\text { introduction of the SCAN. } \\
\text { Authors concluded that ED } \\
\text { staff was already doing well } \\
\text { or the SCAN was not } \\
\text { sufficient }\end{array}$ & $\begin{array}{l}\text { Not effective } \\
\text { Increase of } \\
\text { confirmed cases of } \\
\text { abuse was not } \\
\text { significant }\end{array}$ \\
\hline $\begin{array}{l}\text { Sidebotham et al. } \\
\text { BMJ 1997; 315: } \\
\text { 855-56 [21] }\end{array}$ & $\begin{array}{l}-0-18 \text { yrs } \\
\text { - All } \\
\text { presenting } \\
\text { symptoms } \\
-\mathrm{n}=2345\end{array}$ & $\begin{array}{l}2 \text { audits of } 2 \\
\text { months each }\end{array}$ & $\begin{array}{l}\text { United } \\
\text { Kingdom }\end{array}$ & $\begin{array}{l}\text { To show whether procedures } \\
\text { for identifying children thought } \\
\text { to be at risk of abuse were } \\
\text { being followed }\end{array}$ & Prospective & $\begin{array}{l}\text { Education and training of ED } \\
\text { staff, introducing feedback, } \\
\text { and updating the checklist, } \\
\text { consisting of five risk factors } \\
\text { for child abuse }\end{array}$ & $\begin{array}{c}\text { Increase of children } \\
\text { with } 2 \text { or more } \\
\text { indicators discussed } \\
\text { with the on-call } \\
\text { pediatric registrar } \\
0.22 \% \rightarrow 1.32 \% \text { OR } \\
6.095 \% \mathrm{Cl} 1.71-21.2\end{array}$ & $\begin{array}{l}\text { Procedures were being } \\
\text { followed. Checklist } \\
\text { heightens awareness of } \\
\text { those children in whom } \\
\text { there are features that might } \\
\text { cause concern }\end{array}$ & $\begin{array}{c}\text { Effectiveness not } \\
\text { shown } \\
\text { A significant } \\
\text { increase of } \\
\text { suspected abuse, } \\
\text { but no. of confirmed } \\
\text { cases were not } \\
\text { reported } \\
\end{array}$ \\
\hline $\begin{array}{l}\text { Benger et al. BMJ } \\
\text { 2002; 324: } 780-82 \\
{[9]}\end{array}$ & $\begin{array}{l}-0-5 \text { yrs } \\
\text { - Trauma } \\
\text { - } n=2000\end{array}$ & $\begin{array}{l}2 \text { audits of } 3 \\
\text { months each }\end{array}$ & $\begin{array}{l}\text { United } \\
\text { Kingdom }\end{array}$ & $\begin{array}{l}\text { To improve child protection } \\
\text { procedures by increasing the } \\
\text { frequency with which } \\
\text { intentional injury was } \\
\text { adequately documented and } \\
\text { considered by physicians. To } \\
\text { increase the no. of children } \\
\text { referred for further } \\
\text { assessment, thereby } \\
\text { increasing the detection of } \\
\text { child abuse }\end{array}$ & Prospective & $\begin{array}{l}\text { Introduction of a flowchart, } \\
\text { with } 4 \text { questions, in the } \\
\text { patient's file for assessing } \\
\text { child abuse and consulting the } \\
\text { CPR }\end{array}$ & $\begin{array}{l}\text { Increase of cases of } \\
\text { suspected abuse } \\
\text { referred to social } \\
\text { services after } 6 \\
\text { months. The outcome } \\
\text { of referred children } \\
\text { could not be } \\
\text { determined } \\
0.6 \% \rightarrow 1.4 \% \\
\text { OR } 2.33 \\
95 \% \text { Cl } 0.89-6.1\end{array}$ & $\begin{array}{c}\text { Inclusion of a flowchart } \\
\text { increased awareness, } \\
\text { consideration and } \\
\text { documentation of suspected } \\
\text { abuse }\end{array}$ & $\begin{array}{l}\text { Effectiveness not } \\
\text { shown } \\
\text { A non significant } \\
\text { increase of } \\
\text { suspected abuse, } \\
\text { and authors could } \\
\text { not establish no. of } \\
\text { confirmed cases }\end{array}$ \\
\hline $\begin{array}{l}\text { Bleeker et al. Ned. } \\
\text { Tijdsch. Geneeskd. } \\
2005 ; 149: 1620-23 \\
{[14]}\end{array}$ & $\begin{array}{l}-0-17 \text { yrs } \\
\text { - Suspected } \\
\text { cases of } \\
\text { abuse at all } \\
\text { departments } \\
-n=220\end{array}$ & 40 months & $\begin{array}{l}\text { The } \\
\text { Netherlands }\end{array}$ & $\begin{array}{l}\text { To describe characteristics of } \\
\text { child abuse, establish } \\
\text { directives in cases of } \\
\text { suspected abuse and } \\
\text { introduction of a checklist }\end{array}$ & Retrospective & $\begin{array}{l}\text { Evaluation and analysis of } \\
\text { collected information on child } \\
\text { abuse, introduction of a } \\
\text { checklist consisting of } 9 \\
\text { questions }\end{array}$ & $\begin{array}{l}\text { After intervention } 28 \\
\text { cases of confirmed } \\
\text { abuse were detected } \\
\text { at the ED }\end{array}$ & $\begin{array}{c}\text { Increase of detected cases } \\
\text { of confirmed abuse after } \\
\text { introduction of a checklist at } \\
\text { the ED and analysis by } \\
\text { experts }\end{array}$ & $\begin{array}{l}\text { Effectiveness not } \\
\text { shown } \\
\text { No registration of } \\
\text { situation before } \\
\text { introduction of the } \\
\text { intervention }\end{array}$ \\
\hline
\end{tabular}

Table 1. Overview of articles included in this paper.

ED $=$ Emergency Department, CPR $=$ Child Protection Register, CPT $=$ Child Protection Team, SCAN = Suspected child abuse and neglect

* Effective screening method: due to the intervention, the rate of cases of confirmed child abuse increased significantly. 
Table 2. Items used in the checklists of the articles included in this review.

\begin{tabular}{|l|c|c|c|c|}
\hline Item of the checklist & $\begin{array}{c}\text { Pless } \\
\text { et al. } \\
\text { [13] }\end{array}$ & $\begin{array}{c}\text { Sidebotham } \\
\text { et al. } \\
\text { [21] }\end{array}$ & $\begin{array}{c}\text { Benger } \\
\text { et al. } \\
\text { [9] }\end{array}$ & $\begin{array}{c}\text { Bleeker } \\
\text { et al. } \\
\text { [14] }\end{array}$ \\
\hline Findings examination conform history & $\mathrm{X}$ & $\mathrm{X}$ & $\mathrm{X}$ & $\mathrm{X}$ \\
\hline Delay in seeking medical help & $\mathrm{X}$ & $\mathrm{X}$ & $\mathrm{X}$ & $\mathrm{X}$ \\
\hline Inconsistent history & $\mathrm{X}$ & $\mathrm{X}$ & $\mathrm{X}$ & $\mathrm{X}$ \\
\hline $\begin{array}{l}\text { Child/parent behaviour and interaction } \\
\text { appropriate }\end{array}$ & $\mathrm{X}$ & & & \\
\hline $\begin{array}{l}\text { Child/parent reported or showed } \\
\text { evidence of abuse }\end{array}$ & $\mathrm{X}$ & $\mathrm{X}$ & & \\
\hline $\begin{array}{l}\text { Skeletal survey required } \\
\text { Other reason to suspect abuse }\end{array}$ & $\mathrm{X}$ & & & \\
\hline Previously seen at ED & & $\mathrm{X}$ & & $\mathrm{X}$ \\
\hline Head injury or fracture in child $<1 \mathrm{yr}$ & & & & \\
\hline $\begin{array}{l}\text { Action of parents after injury } \\
\text { appropriate }\end{array}$ & & & & \\
\hline $\begin{array}{l}\text { Perpetrator/witness accompanied } \\
\text { child to ED }\end{array}$ & & & & \\
\hline
\end{tabular}


Table 3. Quality assessment of the included articles. When the criterion was sufficiently met 1 point was ascribed.

\begin{tabular}{|l|c|c|c|c|c|}
\hline \multicolumn{1}{|c|}{ Article } & $\begin{array}{l}\text { Detection rate } \\
\text { was assessed } \\
\text { before and after } \\
\text { applying the } \\
\text { intervention }\end{array}$ & $\begin{array}{c}\text { Inclusion } \\
\text { until } \\
\text { minimally } \\
\text { age 16 yrs }\end{array}$ & $\begin{array}{c}\text { All presenting } \\
\text { symptoms } \\
\text { were included } \\
\text { chispected } \\
\text { child abuse } \\
\text { could be } \\
\text { confirmed }\end{array}$ & Score \\
\hline $\begin{array}{l}\text { Pless et al. } \\
\text { Child Abuse Negl } \\
\text { 1987;11:193-200 } \\
\text { [13] }\end{array}$ & 1 & 0 & 0 & 1 & $\mathbf{2}$ \\
\hline $\begin{array}{l}\text { Sidebotham et al. } \\
\text { BMJ 1997;315:855- } \\
56 \text { [21] }\end{array}$ & 1 & 1 & 1 & 0 & $\mathbf{3}$ \\
\hline $\begin{array}{l}\text { Benger et al. BMJ } \\
\text { 2002;324:780-82 } \\
\text { [9] }\end{array}$ & 1 & 0 & 0 & 0 & $\mathbf{1}$ \\
\hline $\begin{array}{l}\text { Bleeker et al. Ned. } \\
\text { Tijdsch. Geneeskd. } \\
\text { 2005;149:1620-23 } \\
\text { [14] }\end{array}$ & 0 & 1 & 1 & & $\mathbf{3}$ \\
\hline
\end{tabular}




\section{Competing interests:}

No competing interests.

\section{Acknowledgements:}

No Acknowledgements.

\section{Funding:}

This study was funded by the Netherlands Institution for Health Research and Development (ZonMw 633000 23). The authors were completely independent from funders in conducting this study and writing this manuscript.

\section{What is already known about this topic}

- Early detection and intervention may help to halt child abuse and limit the damage to the development of the child.

- With structured registration forms, documentation of the consideration of child abuse and documentation of risk factors increases.

\section{What this study adds}

- Introduction of an intervention resulted in an increase in the rate of suspected cases of abuse in all studies, as well as improved documentation of patient files, and a higher level of awareness of child abuse among ED staff.

- Interventions at ED to increase the detection rate of cases of confirmed abuse could be effective, but currently there is no hard evidence to confirm this.

\section{Copyright License Statement}

E.C.F.M. Louwers has the right to grant on behalf of all authors and does grant on behalf of all authors, an exclusive license on a worldwide basis to the BMJ Publishing Group Ltd and its Licensees to permit this article to be published in ADC and any other BMJPGL products to exploit all subsidiary rights, as set out in their license. 


\section{REFERENCES}

[1] Butchart A, Phinney Harvey A, Mian M, Furniss T. Preventing child maltreatment: a guide to taking action and generating evidence. Geneva: WHO 2006.

[2] Sedlak AJ, Broadhurst DD. Executive Summary of the Third National Incidence Study of Child Abuse and Neglect. 1996, 2007 [cited 2008-06-12].

[3] Ijzendoorn van M.H., Prinzie P., Euser E.M., Groeneveld M.G., Brilleslijper-Kater

S.N., Noort van- Linden van der A.M.T., et al. De nationale prevalentiestudie mishandeling van kinderen en jeugdigen (NPM-2005). Leiden: LUMC; 2007.

[4] http://www.who.int/topics/child abuse/en/. 2007.

[5] Ethier LS, Lemelin JP, Lacharite C. A longitudinal study of the effects of chronic maltreatment on children's behavioral and emotional problems. Child Abuse Negl. 2004;28(12):1265-78.

[6] Hampton RL, Newberger EH. Child abuse incidence and reporting by hospitals: significance of severity, class, and race. Am J Public Health. 1985;75(1):56-60.

[7] Hussey JM, Chang JJ, Kotch JB. Child maltreatment in the United States: prevalence, risk factors, and adolescent health consequences. Pediatrics. 2006;118(3):93342.

[8] Palazzi S, de Girolamo G, Liverani T, IchilMa. Observational study of suspected maltreatment in Italian paediatric emergency departments. Arch Dis Child. 2005;90(4):406-10.

[9] Benger JR, Pearce V. Simple intervention to improve detection of child abuse in emergency departments. BMJ. 2002;324(7340):780.

[10] Chang DC, Knight V, Ziegfeld S, Haider A, Warfield D, Paidas C. The tip of the iceberg for child abuse: the critical roles of the pediatric trauma service and its registry. $J$ Trauma. 2004;57(6):1189-98.

[11] Holter JC, Friedman SB. Child abuse: early case finding in the emergency department. Pediatrics. 1968;42(1):128-38.

[12] Kempe CH, Silverman FN, Steele BF, Droegemueller W, Silver HK. The batteredchild syndrome. JAMA. 1962;181:17-24.

[13] Pless IB, Sibald AD, Smith MA, Russell MD. A reappraisal of the frequency of child abuse seen in pediatric emergency rooms. Child Abuse Negl. 1987;11(2):193-200.

[14] Bleeker G, Vet NJ, Haumann TJ, van Wijk IJ, Gemke RJ. [Increase in the number of reported cases of child abuse following adoption of a structured approach in the VU Medical Centre, Amsterdam, in the period 2001-2004]

Toename van het aantal gemelde gevallen van kindermishandeling na een gestructureerde aanpak in het VU Medisch Centrum, Amsterdam, 2001/'04. Ned Tijdschr Geneeskd.

2005;149(29):1620-4.

[15] Higgins JPT GS. Cochrane Handbook for Systematic Reviews of Interventions. Available from www.cochrane-handbook.org. Updated February 2008 [cited 2008; Version 5.0.0].

[16] Dove A, Kobryn M. Paediatric nursing: computer detection of child abuse. Nurs Stand. 1991;6(10):38-9.

[17] Flanagan NM, MacLeod C, Jenkins MG, Wylie R. The Child Protection Register: a tool in the accident and emergency department? Emerg Med J. 2002;19(3):229-30.

[18] King W, Reid C. National audit of emergency department child protection procedures. Emerg Med J. 2003;20(3):222-4.

[19] McKinney A, Lane G, Hickey F. Detection of non-accidental injuries presenting at emergency departments. Emerg Med J. 2004;21(5):562-4.

[20] Sanders T, Cobley C. Identifying non-accidental injury in children presenting to A\&E departments: an overview of the literature. Accid Emerg Nurs. 2005;13(2):130-6.

[21] Sidebotham PD, Pearce AV. Audit of child protection procedures in accident and emergency department to identify children at risk of abuse. BMJ. 1997;315(7112):855-6. [22] Sidebotham P, Biu T, Goldsworthy L. Child protection procedures in emergency departments. Emerg Med J. 2007;24(12):831-5.

[23] Bar-on ME, Zanga JR. Child abuse: a model for the use of structured clinical forms. Pediatrics. 1996;98(3 Pt 1):429-33.

[24] Limbos MA, Berkowitz CD. Documentation of child physical abuse: how far have we come? Pediatrics. 1998;102(1 Pt 1):53-8.

[25] Rosenberg NM, Meyers S, Shackleton N. Prediction of child abuse in an ambulatory setting. Pediatrics. 1982;70(6):879-82. 
[26] Nootenboom S. Signalering gemist 2. Triage. 2004;3:7-10.

[27] Benger JR, McCabe SE. Burns and scalds in pre-school children attending accident and emergency: accident or abuse? Emerg Med J. 2001;18(3):172-4.

[28] Carter YH, Bannon MJ, Limbert C, Docherty A, Barlow J. Improving child protection: a systematic review of training and procedural interventions. Arch Dis Child. 2006;91(9):740-3.

[29] Clark KD, Tepper D, Jenny C. Effect of a screening profile on the diagnosis of nonaccidental burns in children. Pediatr Emerg Care. 1997;13(4):259-61.

[30] Rowe DS, Leonard MF, Seashore MR, Lewiston NJ, Anderson FP. A hospital program for the detection and registration of abused and neglected children. $\mathrm{N}$ Engl $\mathrm{J}$ Med. 1970;282(17):950-2.

[31] Hight DW, Bakalar HR, Lloyd JR. Inflicted burns in children. Recognition and treatment. JAMA. 1979;242(6):517-20.

[32] Van Haeringen AR, Dadds M, Armstrong KL. The child abuse lottery--will the doctor suspect and report? Physician attitudes towards and reporting of suspected child abuse and neglect. Child Abuse Negl. 1998;22(3):159-69.

[33] Keshavarz R, Kawashima R, Low C. Child abuse and neglect presentations to a pediatric emergency department. J Emerg Med. 2002;23(4):341-5. 


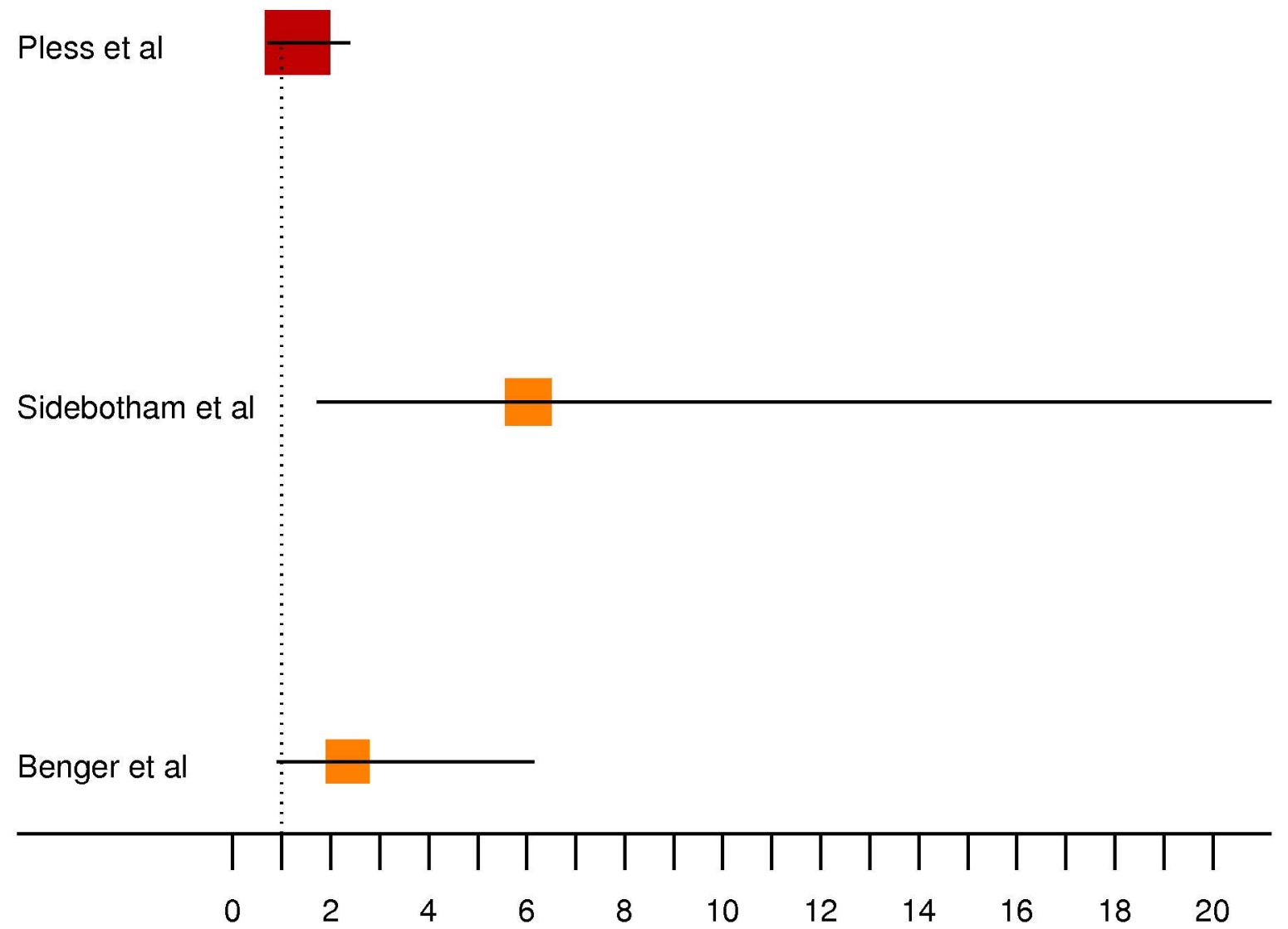

